\title{
Duvar Resimlerinin Mimari Mekânlar Bağlamında Analizi
}

\author{
Tütem TURAN ${ }^{1 *}$ (D) , Begüm ERÇEVIK SÖNMEZ 2 (D) \\ ORCID 1: 0000-0002-6690-9431 \\ ORCID 2: 0000-0001-9435-6443 \\ ${ }^{1}$ Istanbul Gedik Üniversitesi, Güzel Sanatlar ve Mimarlık Fakültesi, İç Mimarlık ve Çevre Tasarımı Bölümü, 34876 \\ istanbul, Türkiye. \\ ${ }^{2}$ Yeditepe Üniversitesi, Mimarlık Fakültesi, l̇ç Mimarlık Bölümü, 34755, İstanbul, Türkiye.

\section{Öz} \\ *e-mail: tutemturan@gmail.com \\ Duvarlar mekânı sınırlama görevi üstlenirken; duvar resimleri ise tarihi yansıtmış, sanat ile kullanıcı arasında \\ iletişim sağlamış, kurumsal kimliği sergilemiş, toplumsal olaylara ışık tutmuş, kullanıcıyı etkileyerek mekânı \\ monotonluktan kurtarmıştır. Mimari tasarımlarda, duvar resimlerinin kullanıcıyı etkileme ve dikkat çekme gücü \\ ile özellikle kullanıcı yoğun mekânlara sağlayabileceği olumlu katkılar es geçilmektedir. Bu çalışmada, mimari \\ yüzey, yapı ve mekânlarda yer alan duvar resimlerini belirlemek ve konsept-mekân bütünlüğü üzerinden analiz \\ etmek amaçlanmıştır. İstanbul'un çeşitli semtlerinin iç ve dış mekânlarında konumlanmış duvar resimleri tespit \\ edilmiş; yerinde gözlemler yapılmış ve tablolar üzerinden değerlendirilmiştir. Duvar resimleri iç mekânlarda \\ estetik katkı sağlamak amacı ile tercih edilmiş, dış mekân yüzeylerinde ise festival düzenleyen firmalar ve Graffiti \\ sanatçıları tarafından kullanılmış ve politik mesajlara rastlanılmamıştır.
}

Anahtar Kelimeler: Duvar resmi, iç mekân, dış mekân

\section{The Analysis of the Wall Paintings in the Context of Architectural Spaces}

\begin{abstract}
The walls assume the task of limiting the space; whereas the wall paintings reflected the history, provided the communication between art and the user, has displayed its corporate identity, shed light on social events, and has saved the place from monotony by affecting the user. In the architectural designs, the positive contributions of wall paintings to user-intensive spaces with the power of affecting and attracting attention are ignored. In this study, it is aimed to determine the wall paintings in the architectural surfaces, buildings and spaces, and to analyze them through concept-space integrity. The wall paintings located in the interiors and the exteriors of the various districts of Istanbul have been identified. On-site observations were done and the data were evaluated on the tables. The wall paintings were preferred in order to contribute to the aesthetics in the interior spaces, on the exterior surfaces, they were used by festival organizers and Graffiti artists, and no political messages were encountered.
\end{abstract}

Keywords: Wall painting, indoor, outdoor

Atıf/Citation: Turan, T, Erçevik Sönmez, B. (2021). Duvar Resimlerinin Mimari Mekânlar Bağlamında Analizi. Journal of Architectural Sciences and Application, 6 (1), 288-300. DOI: 10.30785/mbud.821836 


\section{Giriş}

Duvarlar, mimarinin en önemli parçasını oluşturur. Boşluğun sınırsal çizgilerini ve formlarını belirler. Tarihsel olarak ilk insanlar mağara kayalarını sınır olarak belirlemiş; yüzyıllar boyu gelişen teknoloji ile birlikte zamanla duvarların malzemesi farklılık göstermiştir. Duvar, Büyük Larousse'nin ilgili maddesinde, "üst üste konmuş ve çoğu kez bir harçla birleştirilmiş gereçlerden oluşan, genellikle düşey bir düzlem biçiminde görünen kâgir yapı işi" olarak tanımlanmaktadır. Doğan Hasol'un Mimarlık Sözlüğü'nde ise "yapılarda taş, tuğla, briket, kerpiç ve benzeri gereçlerle yapılan düşey bölme öğesi" olarak tanımlanmaktadır (Hasol, 2016).

Duvarlar mimari formları sınırlayarak alanlar yaratmışlardır. Mekânları oluşturan duvarlar eski çağlardan beri insanlar tarafından görsel estetik dışında, resmin konusu itibari ile mesaj sağlayan yüzeylere dönüştürülmüştür. Tarihsel dönemlerin sosyolojik ve politik konjonktürüne göre mimari yapılarla birlikte duvar resminin hikâyesi de farklılaşmıştır. Günlük yaşam, mitoloji, dinsel öğeler ve politika konuları tarih boyunca mimari yapılara ve mekânlara resmedilmiştir. Günümüzde duvar resmi ticari mekânlar tarafından tercih edilmeye başlanmıştır. Bu noktada duvar resmi ve mekân ilişkisini etkileyen önemli etkenlerden biride ticari mekânlardır. İşletme sahiplerinin kurumsal kimlik adına duvar resimleri üzerinde durmaları, duvar resimlerine verilen önemi arttırmaktadır. Kafe ve restoran gibi kamusal mekânlar kullanıcıların ağırlıklı olarak zaman geçirdiği alanlar olması nedeniyle, firma sahipleri ve tasarımcılar, mekânların akılda kalıcı olmasını sağlamak ve dikkat çekici olması adına duvar resimlerine yönelmişlerdir. Ticari mekânlar arz-talebe göre kısa sürede değişim gösterebilmektedir. Sanatçılar, sokak sanatında ve mimari yapıların dış cephelerinde yer alan eserlerinde daha özgür ve kişisel tavır sergilerken; iç mekânlarda duvar resminin konusunu mekân sahibi ve seçilen konsept belirlemektedir. Duvar resimlerinin ticari mekânlarda kullanılmasının en önemli katkısı, sanatın sadece belli bir kitlenin ulaşabildiği, parasal değeri olan satılık bir nesne konumundan çıkararak daha sosyal bir platforma taşımış olmasıdır.

Mimari tasarımlarda, duvar resimlerinin kullanıcıyı etkileme ve dikkat çekme gücü ile özellikle kullanıcı yoğun mekânlara sağlayabileceği olumlu katkılar es geçilmekte ve tasarımlarda duvar resimlerinin kullanımı özendirilmemektedir. Özellikle iç mekân tasarımlarında hikayesi olmayan yüzeyler ortaya çıkmakta; bu durum konsept ve mekân bütünlügünü olumsuz etkileyebilmektedir. Bu çalışmada mimari yüzey, yapı ve mekânlarda yer alan duvar resimlerinin izini sürmek ve konsept-mekân bütünlüğü üzerinden analiz etmek amaçlanmıştır. Bu doğrultuda, çalışmada aşağıdaki araştırma soruları oluşturulmuştur:

1. Duvar resimlerinin mekândaki işlevi nedir? Bu işlev estetik midir yoksa olay anlatma, politik mesaj verme ya da bilgi verme amacı da var mıdır?

2. Duvar resimlerinin hikayesi nedir?

3. Duvar resimlerinin konsept ile bütünlüğü nedir?

4. Duvar resimlerinin yüzeye, mekâna, kullanıcıya ve mekân sahibine katkısı nedir?

Bu çalışma duvar resminin mekân ile ilişkisini gündeme getirmesi açısından önem taşımaktadır. Mekân tasarımlarında sıklıkla karşılaşılmayan fakat estetik değeri ile kullanıcısının algı davranışlarını etkileyen duvar resmine dikkat çekilmiştir. Bu çalışma, duvar resimleri üzerinden kullanıcının algı davranışlarının tartışıldığı çalışmalar için ilham verici olabilir.

Duvar resmi ve mekân ilişkisi eski çağlardan günümüze kadar değişim göstermiş, mimari ve sanat tarihine tanıklık etmemizi sağlamıştır. Duvar resminin bugünkü durumunu anlayabilmek için duvar resmi ve mimari ilişkinin tarihsel sürecine değinmek doğru olacaktır.

Paleotik dönemde insanlar gözlemledikleri dünyayı mağara duvarlarına resmetmiştir. İspanya'da bulunan Altamira Mağarası'nda bulunan resimler için araştırmacı Max Raphael, gelişigüzel yapılmadıklarını, birbirleriyle uyumlu bir yapıya sahip olduklarını belirtmiştir. Ayrıca Raphael, aynı hayvanların bir mağaradan ötekine tekrar ve tekrar resmedildiğini gözlemlemiştir. Araştırmacı Paleotik dönemde yaşamış insanların şu anda bize yabancı gelecek şekilde mekân tasviri yaptıklarına inanmaktadır. Bu resmetme biçimi iki klanın ittifakını veya bir klanın diğeri üzerindeki hâkimiyetini ifade ediyor olabileceğini belirtmiştir (Curtis, 2017). 
Altamira Mağarası'nın tavanında gelişigüzel gözüken bu resimler bir eksen etrafında toplanmış tek bir kompozisyondan ibarettir. Bu çizimlerin yatay, dikey ve diyagonal olarak düzenlenmiş olduğu görülmektedir (Şekil 1).

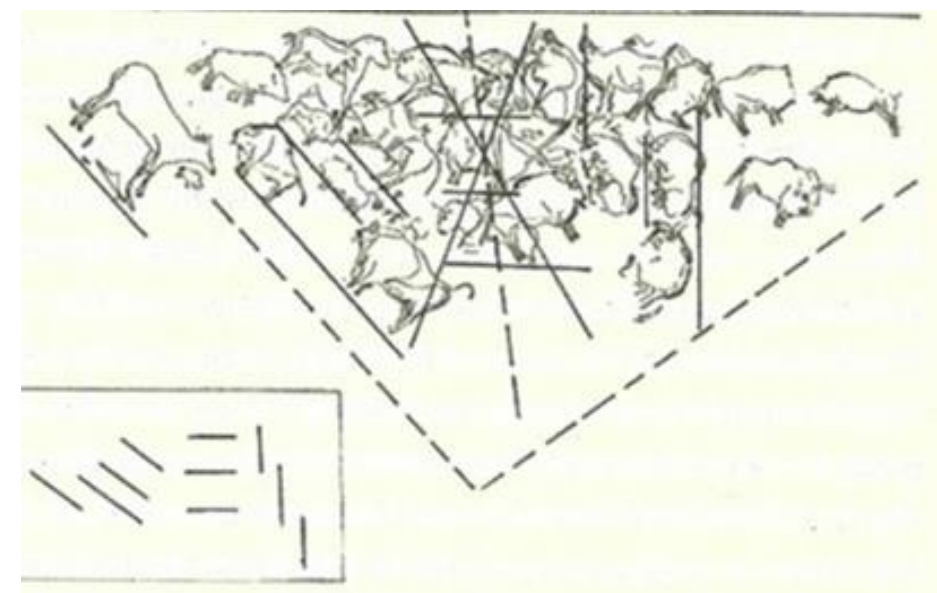

Şekil 1. Max Raphael tarafından analiz edilmiş olan tavan, Altamira, İspanya, MÖ 35.000 -MÖ 11.000 (Curtis, 2017)

Paleotik çağ sonrası gelişen toplumların duvara aktardıkları konular da farklıık göstermiştir. Antik dönemin duvar resimleri o dönemde yaşamış insanların hayatlarına, Paleotik Dönemden daha fazla ışık tutmaktadır. Toplulukların gelişmesi ve kültür kavramının yavaş yavaş ortaya çıkması, her topluluğun kendine özgü eserler üretmesine sebep olmuştur.

Duvar resimlerini özellikle mezar odaları ve anıtsal yapılarda ustalıkla kullanan medeniyetlerden biri de Mısır'dır. Mısır duvar resimlerinde kullanılan katı geometrik düzen, naif perspektif ve doğanın incelikle tasvir edilmesi, ölümden sonraki yaşam bir başka deyişle yeniden doğuş fikrine hizmet eder. Sanatçının kompozisyona yerleştirdiği nesne, hayvan ya da insan imgeleri, simge olmaktan çok, betimledikleri varlıkların yerine geçerler. Bu resimlerin yapılış amaçları onlara yüklenen anlam ya da görevle ilişkilidir (Özdemir, 1991).

Antik Roma döneminde duvar resmi konuları manzara, mitoloji ve erotik öğeleri içermiştir. Çoğunlukla mitolojik öğelerin süslediği duvarlar evlerde yerini almıştır. Roma döneminde evlerin çoğu alanı boyanmıştır. Renklenen ve zenginleşen hayatlarla birlikte duvar resmi konuları çoğalmıştır. Çizimler mekânsal olarak farklılık göstermeye başlamış; renk pigmentlerinin de artması ile birlikte yapılar çok renkli hale gelmişlerdir. Girit Adası'nın kuzeyinde Minos Uygarlı̆ıı'na ait Knossos Saray'ında bulunan Mavi Bayanlar olarak adlandırılan duvar resminde baskın renk dokusu kullanılmıştır (Şekil 2).

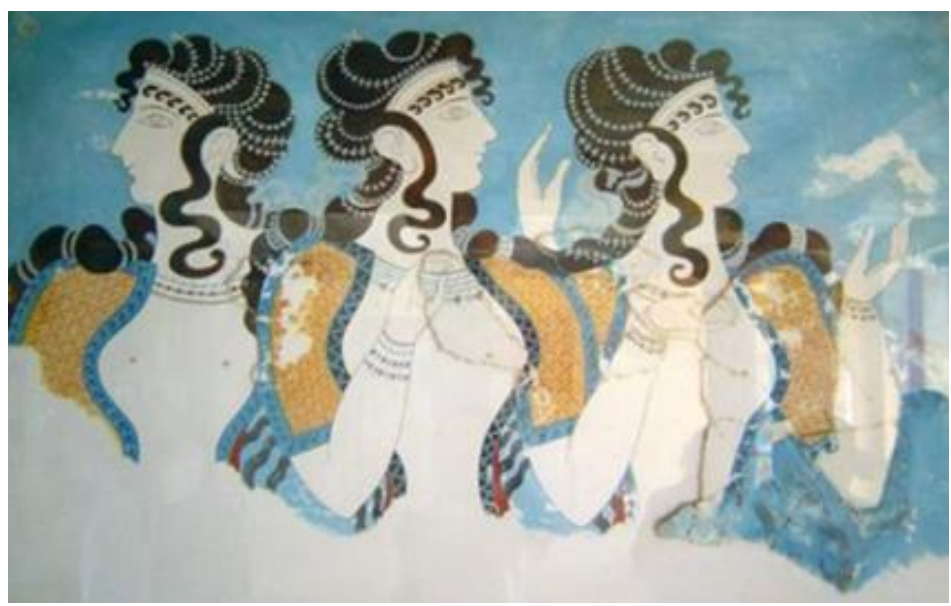

Şekil 2. Knossos Sarayı'ndan mavi bayanlar freski, Girit, MÖ 2700 - MÖ 1450 (Margaryan, 2019)

"Mavi Bayanlar" freski, dönemin zengin kostümleri ile betimlenmiş üç kadını temsil etmektedir. Zarif duruşlu kollara sahip beyaz tenli bayanlar, açıkta kalan göğüsler ve ayrıntılı saç ve mücevherler, belki bir mahkeme festivali veya başka bir önemli sosyal veya dini tören sırasında birbirleriyle sohbet 
ederken tasvir edilir. Mavi bayanların özenli duruşları, Saray Dönemi'nin önemli tören etkinliklerinde onları benimseyen zengin kadınlarını karakterize etmektedir (Art History Attacks, 2011).

10. yüzyıldan sonra İslamiyet'in varlığının başlamasıyla, Hristiyanlığın yayılmasını sağlamak amacıyla duvarlar ikonalarla donatılmıştır (Şekil 3).

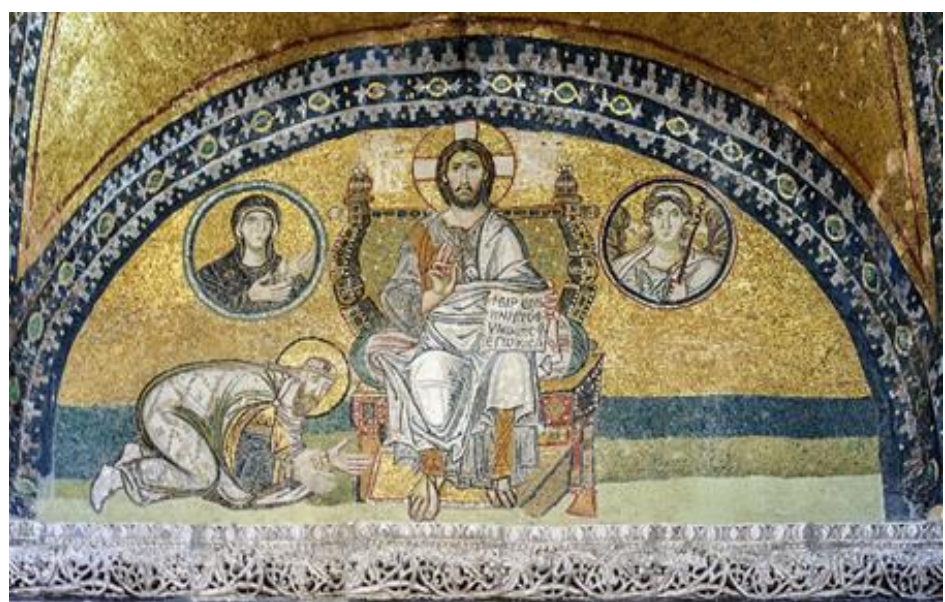

Şekil 3. İsa'nın ayakları önünde secde eden İmp 6. Leon, Ayasofya-i Kebir Cami,10.yy (Wikipedia, 2013)

Erken Bizans döneminde, daha çok Hıristiyanlık ile ilgili konuların ağırlık kazandığı mozaiklerin yapıldığı görülmektedir. Son Bizans Döneminde resim sanatı dinsel tasvirleri konu edinmiş fakat canlı ve hareketli bir üslup göstermiştir. İstanbul semtinde bulunan Kariye Manastır Kilisesinin freskleri son Bizans Döneminde yapılmıştır. Otto Demus'a göre "Kariye evresi hümanist geç Rönesans'a Maniyerist bir eğilimle verilen karşııktır" (Demus, 1975). Gotik mimariye baktığımızda heykel ve vitray ön plana çıkmıştır(Şekil 4). Heykel ve vitraylarda ifade edilen bütün konular Tevrat ve İncil'den alınma dini konular ve dini konularla bütünleşen ve inancı ön plana çıkaran temalardır. Buna rağmen doğa ve insan da güçlü bir biçimde gündelik insan yaşamından gelen etkilerle kaynaşan yeni bir ifade şekliyle ele alınmaya başlanmıştır (Berksaç, 2000).

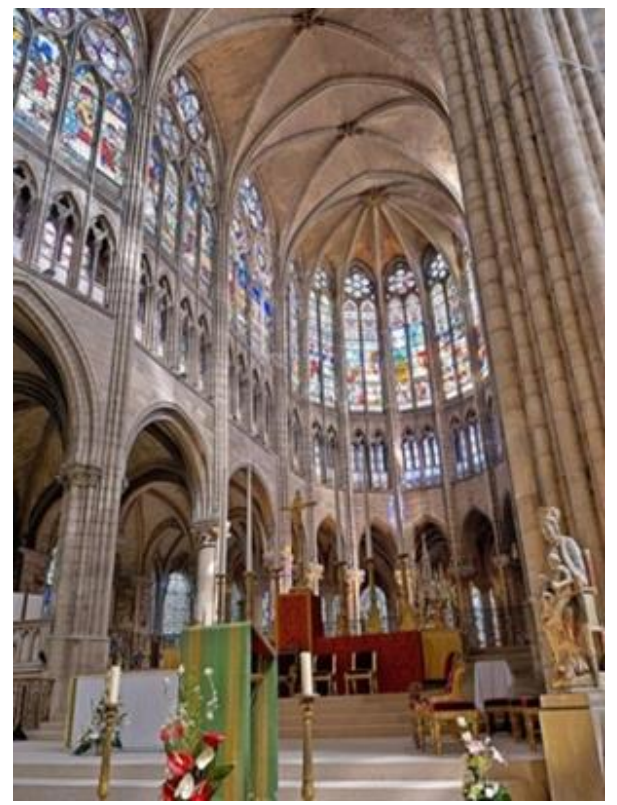

Şekil 4. Saint-Denis Bazilikası, Fransa, 1135 (Wikipedia, 2011)

İtalyan Medici ailesinin sanatçılara destek olması sonucu resim, kilise duvarlarından çıkıp konutlarda belirmeye başlamıştır. Dinsel öğelerin yarattığı kasvetli atmosfer terk edilmeye başlanmış; kullanılan boyalardaki renk skalasının genişlemesi ile dokular daha da belirginleşmiş; perspektifle gelen üçüncü boyut algısı insanları adeta resmin içerisine çekmeye başlamıştır. Mekân, resim, insan bir bütün içerisinde hareket etmeye başlamıştır. Resimlerde hikâyelerin yanında duygu durumları gösterilmeye başlanmıştır. Rönesans sanatçılarının eserlerinde gözlem olgusu ve bunun getirdiği kavrayış hissedilmektedir. Sanatçılar eserlerinde kurallı perspektif, karanlık, aydınlık ve gölge oyunlarını 
kullanmıştır. Leonardo Da Vinci, Rafaello gibi Rönesans Dönemi sanatçıları resimlerinde üç boyut kullanmış; böylece Rönesans yapılarında duvar resimleri sayesinde mekân içinde ikinci birer mekân algısı oluşmuştur (Şekil 5).

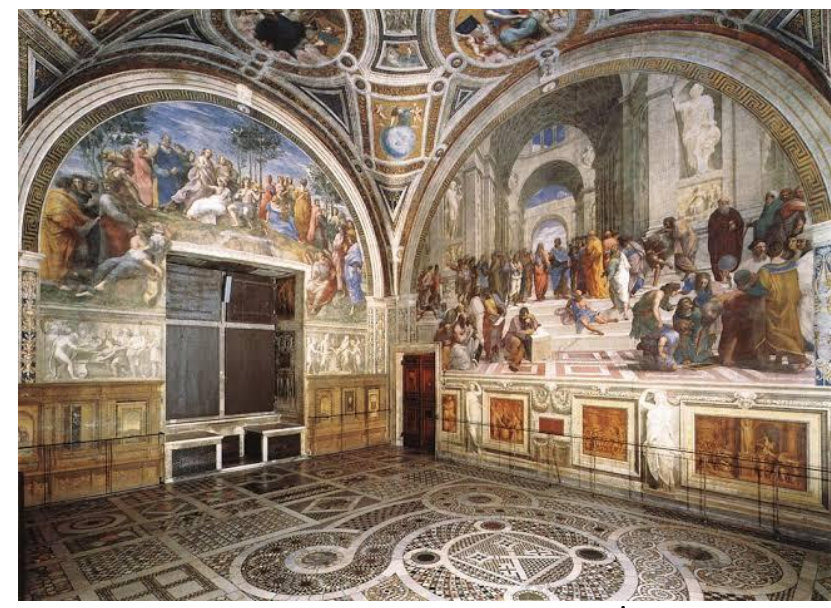

Şekil 5. Raffaello Sanzio, imza salonu freskleri, Vatikan Sarayı, İtalya,1508-1511 (Sardoğan, 2019)

Çağdaş sanat ile duvar resminin mekândaki yeri farklılaşmıştır. İzleyici pasif konumundan ayrılarak artık mekânların içinde daha aktif rol almaya başlamıştır. Bunun ilk örneklerini Avantgarde ve Fütürist sanatçılar ortaya koymuştur. Kamusal mekânlara taşan strüktürler, sanatçıların kurgusal dünyasının dışavurumunu ifade etmiştir.

Kamusal sanatın öncülerinden olan Dadaistler salon sergilerine tepki olarak farklı bir kamusal sanat etkinliği gerçekleştirmişlerdir. 1960'larda Dan Graham, Robert Simitsons ve Gordon Matta-Clark gibi sanatçılar, müzelerin ve galerilerin kamusal alanı yeteri kadar temsil etmediğini ve sanatın "White Box" (Beyaz Kutu) dışına çıkması gerektiğini savunmuşlardır (Tan ve Boynik, 2007).

Modernizm ile birlikte izleyiciye müzelerde sunulan sanat, kentsel meydanlara ve müze dışındaki mekânlarda sergilenir hale gelmiştir. Julie H. Reiss'in (2001) belirttiği gibi “izleyici ile yapıt, yapıt ile mekân, mekân ile izleyici" arasında karşılıklı ilişkinin belirlendiği yeni bir izleme pratiği doğmuştur (Reiss, 2001).

Modern mimari ile işlevsellik ön plana çıkmıştır. Binalar süs ve şekillerden sıyrılmaya başlamıştır (Şekil 6). Brütalizm ve minimalizm gibi akımların kullanıldığı birçok modern mimari tasarım yapılmıştır. Modernizmin rasyonel bakış açısının yeterli gelmediği kimi sanatçılar postmodernizmin de etkisiyle yapı ve mekânlara daha özgür ve hareket katan bir anlayış kazandırmıştır.

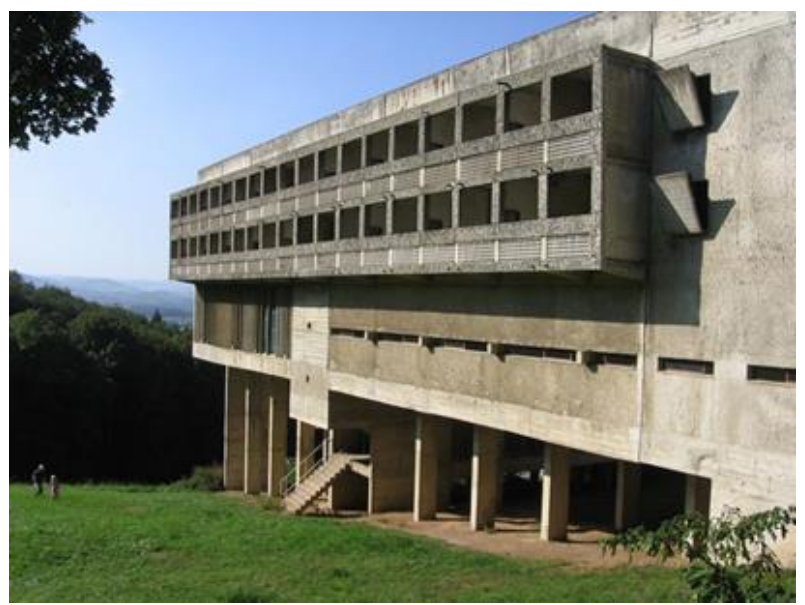

Şekil 6. La Tourette Manastırı, Le Corbusier, Fransa,1960 (Wikipedia, 2007)

Mimari yapıları renk cümbüşüne çeviren sanatçı ve mimar Hudertwasser, modern mimarinin cansız göründüğünü ve düz çizgilerin ise yaratıcılığa engel olduğunu iddia etmektedir. Mimara göre modern binalar, kullanıcıların sağılık ve huzurlarını olumsuz yönde etkilemektedir (Şekil 7). (Restany, 2004). 


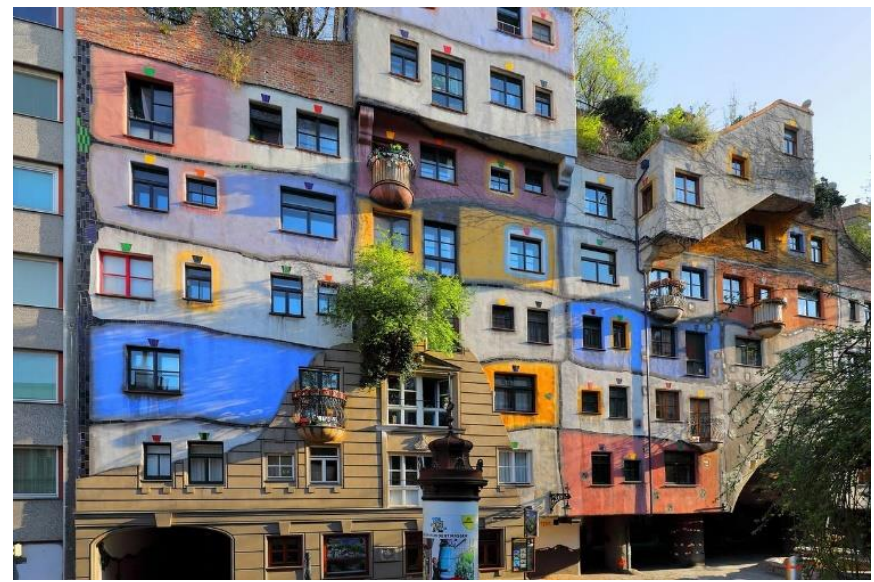

Şekil 7. Hundertwasser evi, Viyana, 1983 (Martinique, 2020)

Duvar resminin günümüz yansımasına baktığımızda mimari dış cephelerde, çoğunlukla graffitiler görülmektedir. Sanatçılar birtakım toplumsal sorunları ve kendi sanatsal görüşünü yansıtmak için herhangi bir kuruma veya kişi desteğine ihtiyaç duymadan çizimlerini illegal tavırla bina cephelerine aktarmaktadır. Fakat kent meydânlarındahi bina cephelerine izinsiz duvar resmi yapmak yasal değildir. Bina cephelerindeki duvar resimleri ifade anlamında daha özgürlükçü bir yaklaşımı konu edinirler. İç mekânlarda ise kamusal mekânlara kıyasla mekânın kurgusuna hizmet edecek konular seçilmektedir. Toplumsal olaylara ışık tutan herhangi bir siyasal yaklaşım, kurumsal kimlik ve marka değeri ile bağdaşmıyorsa ticari mekânlar tarafından tercih edilmemektedir.

Mekân konseptlerinde, duvar resimlerinin işletme sahiplerinin veya tasarımcının önerdiği konular üzerinden var olduğunu görmekteyiz. Yaratılan imajlar duvar resimlerini, insanlar için birer imge haline dönüşmüştür. İnsanlar bir mekâna girdiğinde veya sokaktan geçtiğinde zihinlerinde ortalama birer görüntü oluşur. Bu görüntülerin bütünü imgeleri oluşturur. Zihindeki imgeleri etkileyen önemli bir etken de toplumsal kültür dinamikleridir. Toplumsal kültürün kentte ve mekânlarda oluşturduğu görüntüler sanatçılar tarafından yorumlanıp izleyiciye sunulmuştur. Kamusal sanatın, sadece izleyicinin gördüğü nesne olmaktan çıkıp edilgen bir iletişim aracı haline geldiği varsayılmaktadır. Örneğin; Milano'da bir galeri içerisinde sergilenen Rönesans sanatçısı Pietro Damini'ye ait eser, galerinin kafe bölümünde de kullanılmış ve ziyaretçiler, oturum ve dinlenme zamanlarında da sanat ile iletişim halinde olmuşlardır (Şekil 8). Galerilerin sınırlandırılmış alanlarından çıkan sanat, kentte ve günlük kullanım mekânlarında, sanata ilgisi olmayan insanların dikkatini çekerek izleyici çeşitliliği sağlamıştır.

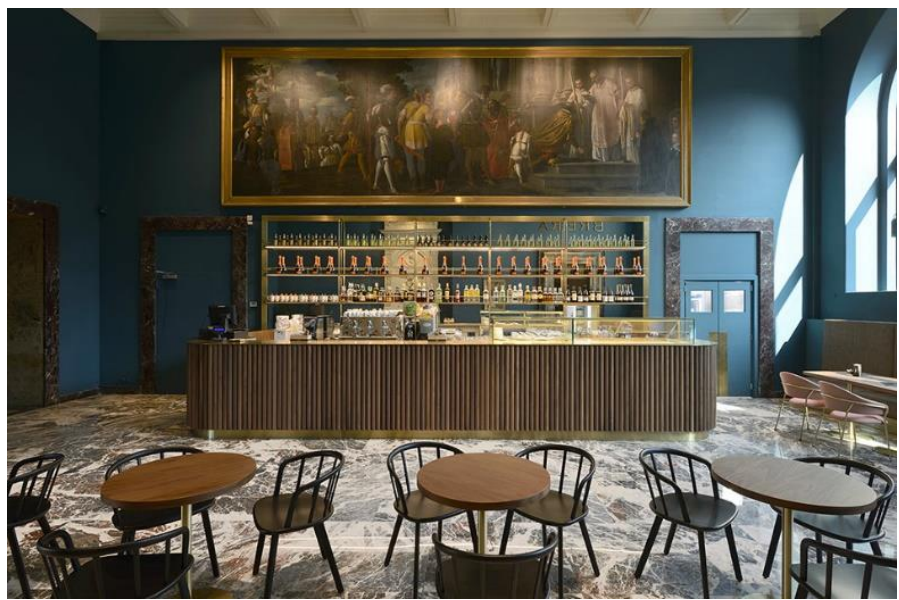

Şekil 8. Caffè Fernanda, Milan, İtalya.2018 (Nastasi, 2021)

Bina yüzeylerinde resim, kabartma sanatı ve serbest plastik çalışmalar giderek büyük boyutlar kazanmaktadır. Bu şekilde bir binanın yüzeysel biçimlenmesi kamusal mekâna önemli çapta varlığını kabul ettirmektedir. Fernand Léger (Şekil 9) ve Juan Miro'nun duvar resimleri (Şekil 10) büyük çapta tablo gibidir. Bugün giderek artan binaların özellikle sağır cephelerini boyama etkinliği, kullanılmayan ve kötü görünüme sahip kentsel boşlukları canlandırma ve iyileştirme çabalarıdır (Ögel, 1977). 


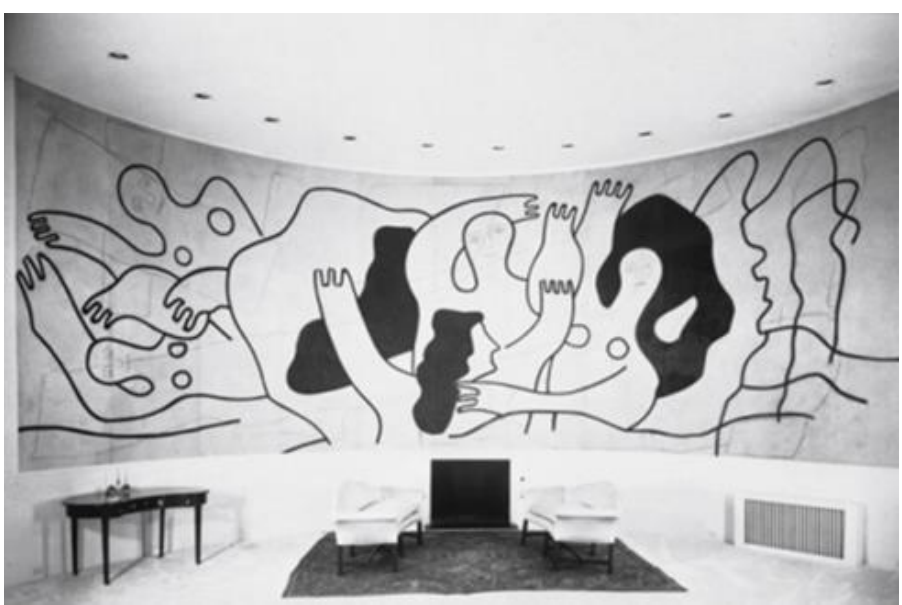

Şekil 9. Wallace K. Harrison evi oturma odası, Fernand Léger, New York, 1942 (Winterhager, 2016)

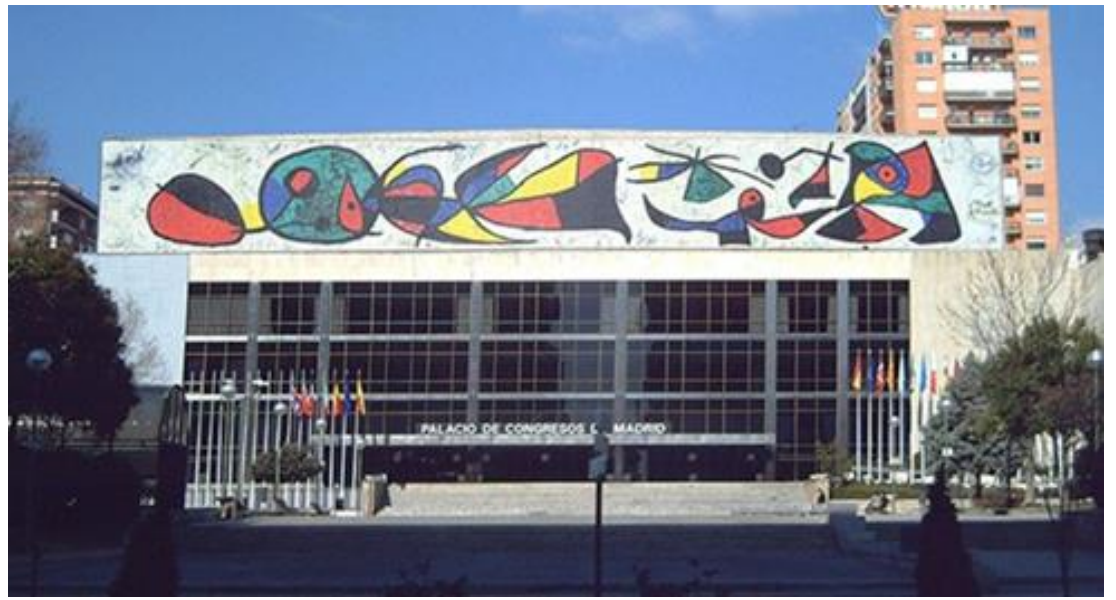

Şekil 10. Kongre ve sergi sarayı , Joan Miro, Madrid,1980 (Südor, 2018)

Duvar resimlerinin günümüzde tercih edilmesinin sebeplerinden biri, mekânların içerisinde ikinci bir mekân yaratarak izleyiciyi ayrı bir kurgu dünyasına çekmesidir. İç mekânlara baktığımızda yaratıcı çizgiler ve formlar sayesinde, yüzeyler ve sınırlar yaratmak mümkündür. Duvar resmi bu noktada üçüncü bir sınır görevi görmektedir. Duvarın işlevinin yanı sıra duvar resmi mekâna hikâye kurgusu katmaktadır.

Duvar resimlerinin iç mimariye göre dış mimari ile ilişkisi daha politiktir. Graffiti ve Hip-Hop kültürünün ilk olarak sokaklarda yaygınlaşmış ve graffitinin kendi içinde illegalliği barındırması sonucu öncelikle bina cephelerinde konumlanmıştır. Ticari mekânlarla iş birliği günümüzdeki gibi yaygın olmamıştır. Günümüzde grafiti ve sanatçılarının toplum tarafından dikkat çekmesi sonucu, duvar resimleri ticari markaların da ilgi odağı haline gelmiştir. Küresel rekabet sonucunda farklı arayışlara giren firmalar ve ülkeler duvar resimleri ile ilgili çeşitli destekler sunmuştur. Washington'da kurulan "Sanat için Ulusal Bağışlar", (National Endowments Art), Amerikalı sanatçılara finansal destek için kurulmuştur. İstanbul'da Kadiköy Belediyesi'nin 2012'den beri düzenlediği "Mural İstanbul Festivali" dünyadan birçok sanatçıyı ağırlamıştır. Aşağıda bu festivalde Lonac tarafından tasarlanmış bir duvar resmi görülmektedir (Şekil 11). 


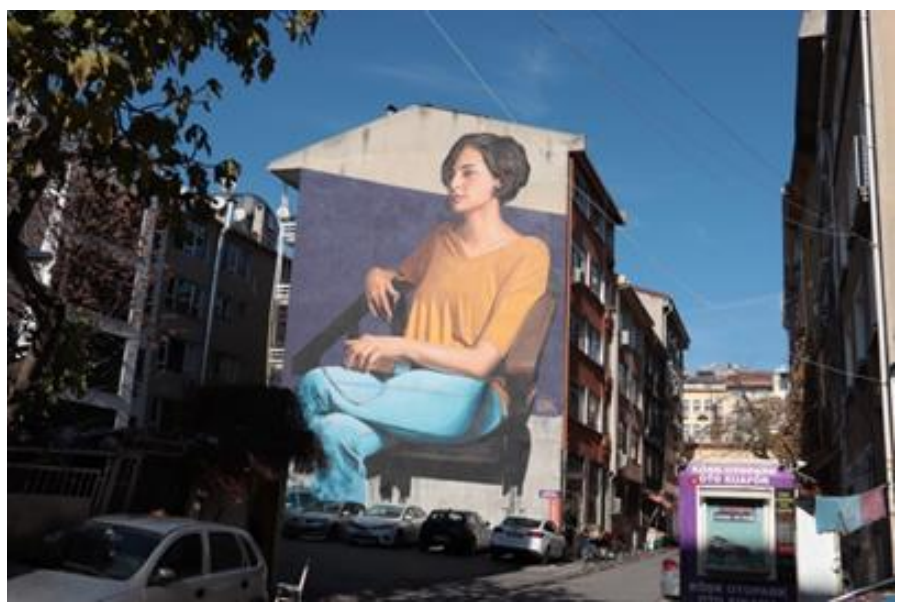

Şekil 11. Lonac, Rasimpaşa Mahallesi, Kırmızı Kuşak Sokak, Kadıköy, İstanbul, 2018 (Turan, 2020)

\section{Materyal ve Yöntem}

Bu çalışmanın temel amacı, mimari yüzey, yapı ve mekânlarda yer alan duvar resimlerini izini sürmek ve konumlandıkları mekân ile ilişkilerini renk, hikâye, mekândaki yeri, işlevi, resmin konsept ile uyumu, resmin aydınlatılması gibi başlıklar üzerinden analiz etmek ve karşılaştırmaktır. Çalışmanın diğer amaçları ise şöyle sıralanabilir:

1. Duvar resimlerinin dış mekânda olduğu kadar iç mekânda da yaygın olduğunu ortaya çıkarmak.

2. Tasarımcılar için ipuçları oluşturmak.

İstanbul' da birçok duvar resmi bulunmaktadır. Duvar resimlerimin izini sürmek için İstanbul'un sık kullanılan yoğun kentsel alanları olan Kadıköy, Beşiktaş, Taksim ve Karaköy seçilmiştir. Araştırma alanı seçiminde, yeme-içme ve alışveriş mekânlarındaki yoğunluk nedeniyle kullanıcıların ilgisini çeken bölgeler tercih edilmiştir. Seçilen dört araştırma alanında, yerinde gözlemler yapılmış ve duvar resimlerinin fotoğrafları çekilmiştir. Çalışma için duvar resimleri gündüz saatlerinde Canon 200D 18$135 \mathrm{~mm}$ fotoğraf makinası ile tam cepheden görülebilecek şekilde fotoğraflanmıştır. Çevreyi kullanan insan yoğunluğunu azaltmak adına çekimler hafta içi sabah saatlerinde gerçekleştirilmiştir. Aşağıdaki tabloda bölgelere göre fotoğraflanan toplam duvar resmi sayısı belirtilmiştir (Çizelge 1).

Çizelge 1. İncelenen duvar resimlerinin bölgelere göre sayısı (Turan, 2020)

\begin{tabular}{lll}
\hline & İç Mekân & Dış Mekân \\
\hline Beyoğlu & 8 & 11 \\
\hline Kadıköy & 8 & 15 \\
\hline Beşiktaş & 9 & İncelenmedi \\
\hline Karaköy & 2 & 2 \\
\hline
\end{tabular}

Fotoğraflanan duvar resimlerinde beş adet iç, beş adet dış mekân olmak üzere toplam on adet duvar resmi konum, sanatçıı adı, tür, akım, renk, duvar resminin hikâyesi, mekândaki yeri, mekândaki işlevi, resmin konsept ile uyumu, resmin aydınlatılması başlıkları üzerinden değerlendirilmiştir. Değerlendirmeye alınan resimlerinin seçiminde şu başlıklar göz önünde bulundurulmuştur: figür ve portre belirli ve net bir şekilde soyutlanmadan çizilmiş resim; Herhangi bir hikâye ve figür belirtmeyen soyut duvar resmi; Toplumca bilinen bir ressamın duvar resmi kurumsal konsept anlatan duvar resimleri; Mekândan bağımsız natürmort çizimler.

Çizelge 2' de seçilen iç mekân duvar resimlerinin ve Çizelge 3'te ise seçilen dış duvar resimlerinin analizi görülmektedir. 
Çizelge 2. İç mekân duvar resimlerinin analizi (Turan, 2020)

\begin{tabular}{|c|c|c|c|c|c|}
\hline $\begin{array}{l}\text { İç Mekân Duvar } \\
\text { Resmi }\end{array}$ & & & & & \\
\hline Konum & $\begin{array}{l}\text { Pim Karaköy } \\
\text { Karaköy }\end{array}$ & $\begin{array}{l}\text { Mamicini Cafe } \\
\text { Kadiköy }\end{array}$ & $\begin{array}{l}\text { White Mill Cafe } \\
\text { Akaretler }\end{array}$ & $\begin{array}{l}\text { Craft Beer Lab } \\
\text { Akaretler }\end{array}$ & $\begin{array}{l}\text { No Fish Today } \\
\text { Akaretler }\end{array}$ \\
\hline Sanatçı Adı & Bilgiye ulaşılamadı. & $\begin{array}{l}\text { Sümeyye } \\
\text { Demirbaş }\end{array}$ & Bilgiye ulaşılamadı. & $\begin{array}{l}\text { Bilgiye } \\
\text { ulaşılamadı. }\end{array}$ & Bilgiye ulaşılamadı. \\
\hline Tür & Soyut resim & Enteriyör & Natürmort & Figüratif resim & Portre \\
\hline Akım & Kübizm & Pop-Art & Realizm & Realizm & Pop-Art \\
\hline Renk & Çok renkli & $\begin{array}{l}\text { Nötr } \\
\text { (Siyah/Beyaz) }\end{array}$ & Renkli resim & $\begin{array}{l}\text { Monoktom(Pastel } \\
\text { tonlar/Kahve) }\end{array}$ & Monokrom/Yeşil \\
\hline Hikâye & $\begin{array}{l}\text { Çeşitli meslek } \\
\text { dallarından } \\
\text { insanlarn } \\
\text { oluşturduğu } \\
\text { kompozisyondur. }\end{array}$ & $\begin{array}{l}\text { Sokak tasvirleri } \\
\text { yapılmıştır. }\end{array}$ & $\begin{array}{l}\text { Çiçek desenlerine } \\
\text { ait bir } \\
\text { kompozisyondur. }\end{array}$ & $\begin{array}{l}\text { Elinde şişe tutan } \\
\text { erkek figür } \\
\text { frontal bir } \\
\text { duruşla tasvir } \\
\text { edilmiştir. }\end{array}$ & $\begin{array}{l}\text { Genç bir kadın figür } \\
\text { yan profilden tasvir } \\
\text { edilmiştir ve bakış } \\
\text { yönü mekâna } \\
\text { doğrudur. }\end{array}$ \\
\hline Mekândaki Yeri & $\begin{array}{l}\text { Restoran giriş } \\
\text { kapısı yanı }\end{array}$ & $\begin{array}{l}\text { Restoran giriş } \\
\text { kapısı çevresi }\end{array}$ & Restoran alt kat & $\begin{array}{l}\text { Restoran giriş } \\
\text { kapısı karşı yan } \\
\text { cephe }\end{array}$ & $\begin{array}{l}\text { Restoran giriş kapısı } \\
\text { karşı duvar }\end{array}$ \\
\hline Mekânın Konsepti & Retro & Retro & Loft & Loft & Loft \\
\hline Mekândaki İşlevi & Dekoratif & Dekoratif & Dekoratif & Dekoratif & Dekoratif \\
\hline $\begin{array}{l}\text { Resmin Konsept ile } \\
\text { Uyumu }\end{array}$ & $\begin{array}{l}\text { Uyumsuz. Mekâna } \\
\text { göre çok renkli. }\end{array}$ & $\begin{array}{l}\text { Uyumlu. Mekân } \\
\text { mobilyaları ile } \\
\text { uyumlu. }\end{array}$ & $\begin{array}{l}\text { Uyumsuz. Klasik } \\
\text { tavır Loft tasarımı } \\
\text { ile bağdaşmıyor. }\end{array}$ & $\begin{array}{l}\text { Uyumlu. Mekân } \\
\text { renkleri ve } \\
\text { mobilyalarla } \\
\text { uyumlu. }\end{array}$ & $\begin{array}{l}\text { Uyumlu. Klasik resim } \\
\text { klasik mobilyalarla } \\
\text { bütünleşmiş, } \\
\text { resimdeki pop-art } \\
\text { çizgiler Loft akımı ile } \\
\text { bağdaşıyor. }\end{array}$ \\
\hline $\begin{array}{l}\text { Resmin } \\
\text { Aydınlatılması }\end{array}$ & $\begin{array}{l}\text { Duvar üstü spot } \\
\text { aydınlatma }\end{array}$ & Duvar üstü aplik & $\begin{array}{l}\text { Tavan altı spot } \\
\text { aydınlatma }\end{array}$ & $\begin{array}{l}\text { Tavan altı spot } \\
\text { aydınlatma }\end{array}$ & $\begin{array}{l}\text { Tavan altı spot } \\
\text { aydınlatma }\end{array}$ \\
\hline
\end{tabular}


Çizelge 3. Dış mekân duvar resimlerinin analizi (Turan, 2020)

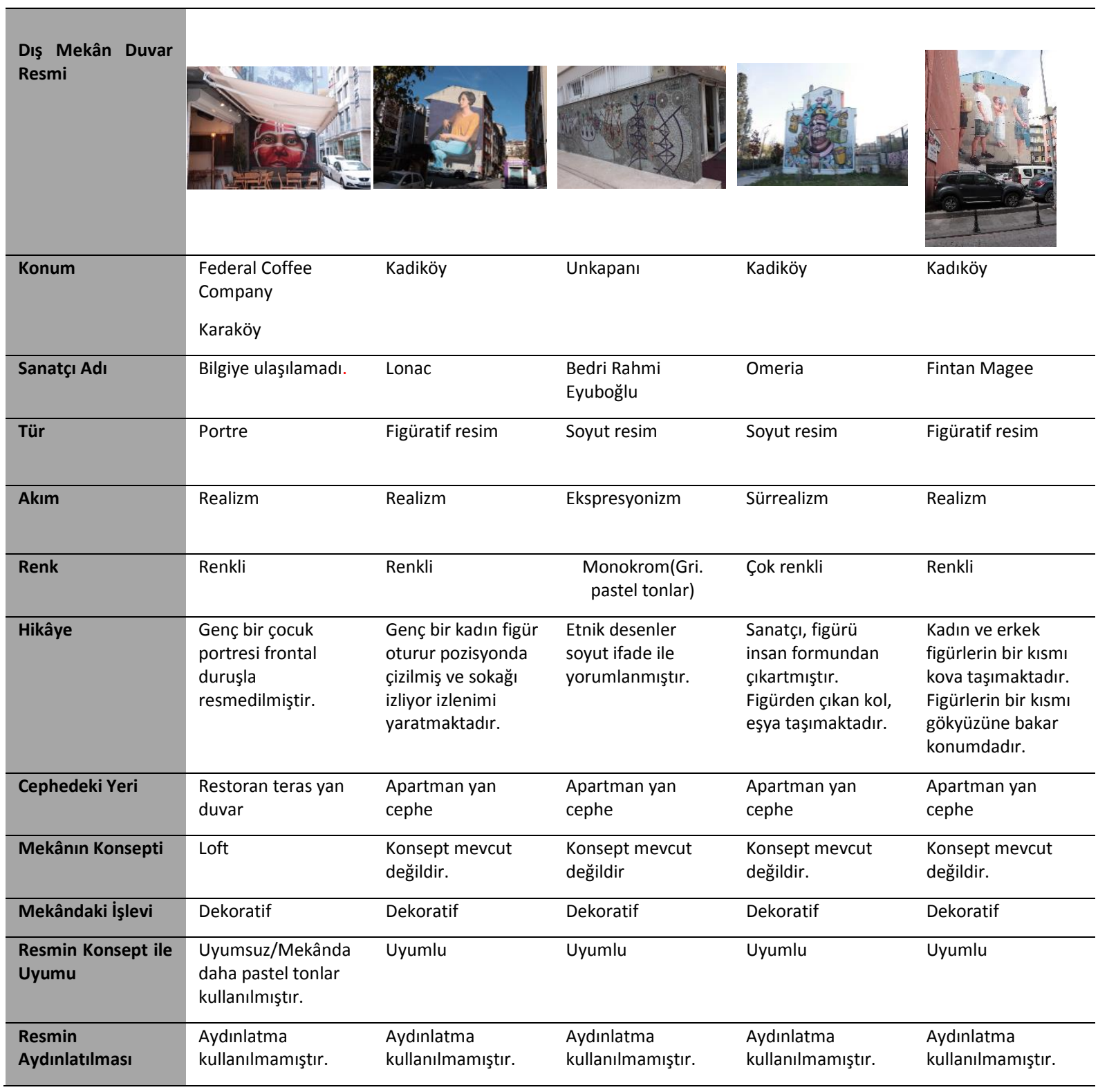

\section{Bulgular}

İzi sürülen iç mekân duvar resimlerinin Kadıköy, Karaköy ve Akaretler'de konumlanan kafe iç mekânlarında yer alırken, dış mekân duvar resimleri ise Unkapanı, Kadıköy, Beyoğlu ve Karaköy'de bulunmaktadır. İç mekân duvar resimlerinin sadece bir tanesinin sanatçı bilgisine ulaşılmıştır. Mamicini Cafe'nin içinde konumlanan grafiti Sümeyye Demirbaş tarafından tasarlanmıştır. Çalışmada incelenen iç mekân duvar resimlerinin türlerinin çeşitlilik gösterdiği görülmektedir. Grafiti, Natürmort ve Portre gibi türlerinde tasarlanan iç mekân duvar resimlerinde Hip-Hop, Pop- Art, Klasik akımlarından yararlanılmıştır. Renk seçimlerinde de çok renkli çalışmalar olduğu gibi monokrom ve kontrast renk kullanımları da göze çarpmaktadır. İç mekân duvar resimleri genellikle giriş ve girişin yakın çevresinde konumlanmaktadır. İç mekân resimleri, ağılıklı olarak, çalışmada Loft olarak kabul edilen açık kirişli, yüksek tavanlı, beton ve tuğlanın kullanıldığı, geniş ve açık mekân konseptlerinde gözlenmiştir. Dış mekânlarda resim bina cephesinde bulunduğundan belirli bir konseptten bahsetmek mümkün değildir. Oysa Koçak ve diğerleri'ne (2014) göre kamusal sanat, kimliği tanımlı ya da yeniden yaratmalı, birey ile mekân arasında bir bağlantı geliştirmeli, özellikle de bir yere ve / veya topluluğa ait olma hissi sağlamalıdır. 
Duvar resimleri çoğunlukla mekânlarla uyum içerisindedir. Duvar resimleri iç mekânlarda aplik ve spot ile aydınlatılmıştır. Çizelge 2'de görüldüğg̈ü üzere sadece Pim Karaköy'de duvar resmi için özel aydınlatma kullanmıştır. Dış mekân duvar resimlerinde ise aydınlatma kullanılmamıştır.

Firma sahipleri ve sanatçılarla yapılan yüz yüze görüşmeler sonucunda aşağıda yer alan bulgulara ulaşılmıştır:

Mekânlarında duvar resmi kullanan firma sahipleri duvar resimlerini görsellik ve dikkat çekmek amacı ile tercih etmişlerdir. İç mekânlarda firma sahipleri şaşırtma, eğlendirme ve dikkat çekme amacı ile resim yapılmasını istemiştir. Özçam'ın (2019)araştırması görüşme sonuçlarına doğrular niteliktedir. Buna göre, enstalasyonlar ve duvar resimleri hatırlanabilir müşteri deneyimleri yaratmak, müşterinin mekânla etkileşimini arttırmak ve kurum kimliğine ilişkin mesajlar vermek amacıyla kullanılabilir. Diğer tercih sebeplerinden biri de resmin sosyal medyada paylaşılması ve böylelikle mekânın reklamının yapılmasını sağlamaktır. Klein'e (2016) göre illegal sokak sanatı olan grafiti sosyal ağlar aracılığı ile meşru hale gelmeye başlamıştır. Diğer taraftan, kimi markalar tasarım odaklı sanatsal dokunuşlara öncelik verdiği için duvar resimlerini tercih etmişlerdir. Firma sahipleri duvar resimleri sayesinde mekânlarına gelen müşteri sayısının arttığını belirtmişlerdir çünkü kullanııılar, sadece sanatsal bir nesneyi tüketen ve alkışlayan pasif izleyiciden farklı olarak, grafiti sanatını fotoğraflayan, paylaşan, politik olarak ilişkisini sorgulayan bireylere dönüşmüştür (Júnior, 2016).

Duvar resmi uygulayan sanatçılara baktığımızda ise özel firmalardan ücret aldıklarını ve firmaların markalarını ve ilgi alanlarını yansıtan resimler yaptıklarını vurgulamışlardır. Sokak sanatçıları ilhamlarını sokakta yaşanan olaylardan aldıklarını söylemişlerdir. Bengster (2018), benzer bir şekilde, sokak sanatının, günlük çevreyi bir keşif sahasına dönüştürdüğünü, insanların günlük rutinlerinden kesitler sunduğunu belirtmiştir.

\section{Sonuç ve Öneriler}

Bu çalışmada İstanbul örneği üzerinden mevcut duvar resimleri incelenmiş ve konumlandıkları mekân ile ilişkilerini renk, hikâye, mekândaki yeri, işlevi, resmin konsept ile uyumu, resmin aydınlatılması gibi başlıklar üzerinden değerlendirilmiştir. Değerlendirmelerin sonuçları şöyle sıralanabilir:

- Duvar resimleri, iç-dış mekânlarda sadece görsel estetik sağlamak amacı ile kullanılmıştır.

- Resmedilen hikâyeler özellikle iç mekânlarda ya geçmişin bir reprodüksiyonu olarak ortaya çıkmış ya da bütünlük sağlamayan birbirinden kopuk resimler olarak kalmıştır.

- iç mekânlarda duvar resmi ağırlıklı olarak Loft konseptle sahip restoranlarda yerini almıştır. Resmin konumlandırıldığı yer kullanıcıların görüş alanını kapsayacak şekilde giriş kapısı yan ve karşı cephe olarak doğru bir şekilde konumlandırılmıştır. Bazı mekânlarda duvar resmi tek bir cepheyi kapsarken bazı konseptlerde birkaç duvarda birden yer almıştır. Duvar resminin konuları ve hikâyesi mekân konseptleriyle genelde uyuşmamaktadır fakat resim renk tonları açısından konseptler ile çoğunlukla uyumlu olduğu görülmüştür. Konuların daha çok firma sahipleri ve sanatçıların kişisel istekleri doğrultusunda gelen müşteriye görsel estetik sağlamak amacı ile yapıldığı ortaya çıkmıştır. Duvar resimlerinin görsel olarak bir duvarı kaplama dışında mekâna herhangi bir katkısı yoktur. Resim aydınlatmalarında bölgesel spot aydınlatmalar kullanılmıştır.

- Dış mekânlarda duvar resimleri ise geniş sokaklar, dört yol ağzı ve birçok açıdan görünür yapıların yan cephelerinde yerini almıştır. Konuların daha çok sanatçıların kişisel tercihine bırakıldığı görülmüştür. Resim konularında politik herhangi bir söyleme rastlanmamıştır. Duvar aydınlatmaları yetersizdir hatta hiç yoktur.

Değerlendirmeler doğrultusunda tasarımcılar için bazı ipuçları oluşturulmuştur:

- Duvar resminin mekân dokusu ve konseptiyle uyum içerisinde olması mekânlara estetik açıdan katkı sağlar.

- Duvar resminin mekânla bütünlük sağlanması isteniyorsa renk seçiminde benzer tonlar kullanılması; duvar resminin dikkat çekmesi ve vurgulanması isteniyorsa mekânda kullanılan renklerin kontrastı olan renklerin kullanılması önerilir. 
- Duvar aydınlatmaları spot ışıklarla aydınlatılarak daha belirgin hale getirilmelidir.

- Duvar resimlerinin, yaygın ve dağınık olarak kullanılması yerine her yerden görülebilen tek bir duvarda yer alması daha etkili olacaktır. Eğer birden çok duvar seçilecekse, çizimlerin aynı türde olması önerilir.

- Hikâye ve konunun, mimari form ve mekân konseptinden farklı olarak seçilmemesi gerekmektedir.

- Duvar resminin konusunun ve çizim tekniğinin sanatsal değerinin olması, mimari mekânlara özgünlük sağlayabilecektir.

- Duvar resimleri özellikle vurgulanmak isteniyorsa iç mekânlarda spot ile aydınlatılmalıdır. Dış mekânlarda ise duvar resimleri kent meydanlarından akşam saatlerinde görülebilmesi için aydınlatılmalıdır.

- Duvar resimleri farklı bölücü yüzeylerde yerini alabilir. Yapay zekâ gibi programlarla insanlar resmin bir parçasına katkı sağlayabilir.

- Tasarımcılar ve sanatçılar duvar resmini sadece yüzeye yapılan resim olarak görmemeli; kullanıııların hislerini ve duyularını harekete geçirecek sanatsal ifade de güçlendirilmelidir.

Bu çalışmada İstanbul'daki duvar resimlerinin izleri sürülmüştür. Bu çalışmanın analiz başıkları ele alınarak Anadolu kentlerindeki duvar resimlerinin de izleri sürülebilir ve elde edilen sonuçlar yurtdışı örnekleri ile karşılaştırılabilir. Duvar resimlerinin bireylerde uyandırdığı duygu durumlar tartışılabilir. Bireyler yaş, eğitim, cinsiyet ve sanata ilgi yönünden çeşitli gruplara ayrılabilir ve gruplar üzerinden farklı duvar resimlerinin onlarda hangi tür duygular uyandırdığı incelenebilir. Yapılan analizler sonucunda firmalar ve tasarımcılar, mural sanatçıları ile birlikte mekânlar için ortak çalıştaylar yürütebilirler. Dünyanın birçok yerinde firmaların ve belediyelerin duvar resimlerine yaklaşımları incelenebilir ve ülkeler arası karşılaştırma yapılabilir. Duvar resimleri estetiğin geri planda tutulduğu gecekondu mahallelerinde sanatçılar tarafından uygulandıktan sonra kullanıcı üzerindeki etkileri tartışılabilir. Sonuç olarak, bu çalışma benzer konularda yapılacak araştırmalara örnek teşkil etmektedir.

\section{Teşekkür ve Bilgi Notu}

Bu metin, birinci/sorumlu yazarın İstanbul Gedik Üniversitesi İç Mimarlık ve Çevre Tasarımı Yüksek Lisans Programı'nda hazırlamış olduğu tezinden üretilmiştir. Makalede, ulusal ve uluslararası araştırma ve yayın etiğine uyulmuştur. Çalışmada etik kurul izni gerekmemiştir.

\section{Kaynaklar}

Art History Attacks. (2011). The Ladies in Blue Fresco. Erişim Adresi (22.06.2011): http://arthistoryattacks.blogspot.com/2011/06/artwork-of-day.html

Bengtsen, P.( 2018). Street art and the nature of the city, Lund Studies in Arts and Cultural Sciences,125138.

Berksaç, E. (2000). Avrupa Sanatı'na Giriş. İstanbul: Engin Yayıncılık.

Curtis, G. (2017). Mağara Ressamları. İstanbul: Redingot Yayınları.

Demus, O. (1975). The Style of Kariye Djami and its Place in the Development of Paleologan Art, The Kariye Djami. New Jersey: Princeton University Press.

Hasol, D. (2016). Ansiklopedik Mimarlık Sözlüğü. İstanbul: Yem Yayınları.

Júnior, H. C. (2016). Anonymous Inscriptions in Rio de Janeiro Resistance and informal urban communication on the streets, Street art \&amp; Urban Creativity Scientific Journal,16-21.

Klein, R. (2016). Creativity and territory: the construction of centers and peripheries from graffiti and street art, Street art \&amp; Urban Creativity Scientific Journal,6-15. 
Koçak, D. Ö. ve Koçak, O. K. (2014). Whose City Is That? Culture, Design, Spectacle and Capital in Istanbul. Cambridge Scholars Publishing.

Margaryan, P. (2019). Girit Uygarlı̆ıı'nın Yükselişi ve Çöküşü. Erişim Adresi (21.01.2019): https://arkeofili.com/girit-uygarliginin-yukselisi-ve-cokusu/

Martinique, E. (2020). Hundertwasser evi, Viyana, 1983. Erişim Adresi (21.08.2020): https://www.widewalls.ch/magazine/hundertwasser-house-vienna

Nastasi, M. (2021). Caffè Fernanda. Erişim Adresi https://thespaces.com/caffe-fernanda-recalls-1950smilanese-glamour/ Erişim tarih: 10.02.21

Ögel, S. (1977). Çevresel Estetik. I.T.Ü. Yayınları.

Özçam, I. (2019). Ticari Mekânlarda Enstalasyonla Yaratılan Dinamikler. Tasarım Kuram, 15(27),64-76.

Özdemir, M. (1991). Büyük Boyutlu Duvar Resmi (Fresco-Sıva Üstü) Teknikleri ve Çağdaş Uygulamaları. Dokuz Eylül Güzel Sanatlar Fakültesi, İzmir.

Reiss, J. H. (2001). From Margin to Center-The Spaces of Installation Art. Londra: The MIT Press.

Restany, P. (2004). Hudertwasser. Taschen.

Sardoğan, Ö. (2019). Raffaello Sanzio, İmza Salonu Freskleri. Erişim Adresi (21.01.2019): https://wannart.com/icerik/8381-ronesansin-dort-atlisinin-en-kucugu-raffaello-sanzio-daurbino

Südor, G. (2018). Kongre ve Sergi Sarayı, Joan Miro. Erişim Adresi (25.04.2018): https://www.evrensel.net/haber/350867/resimleri-siirlestiren-siirleri-resimlestiren-katalanressam-miro

Tan, P. ve Boynik, S. (2007). Olasılıklar, Duruşlar, Müzakere-Güncel Sanatta Kamusal Alan Tartışmaları, İstanbul Bilgi Üniversitesi Yayınları, İstanbul.

Turan, T. (2020). Lonac, Rasimpaşa Mahallesi, Kırmızı Kuşak Sokak, Kadıköy, İstanbul, 2018.

Wikipedia (2007). La Tourette Manastırı Erişim Adresi(16.09.2007): https://en.wikipedia.org/wiki/File:Sainte_Marie_de_La_Tourette_2007.jpg\#filehistory

Wikipedia. (2011). Saint-Denis Bazilikası. Erişim Adresi(6.07.2011): https://en.wikipedia.org/wiki/Basilica_of_Saint-Denis

Wikipedia. (2013). İsa'nın Ayakları Önünde Secde Eden İmp 6. Leon. Erişim Adresi (20.01.2013): https://tr.wikipedia.org/wiki/Dosya:Hagia_Sophia_Imperial_Gate_mosaic_2.jpg

Winterhager, U. (2016). Wallace K. Harrison Evi Oturma Odası Erişim Adresi (4.04.2016): https://www.koelnarchitektur.de/pages/de/news-archive/14270.htm 